\title{
A Conceptual Study on Kaphaja Shiroroga with Special Reference to Sinusitis
}

\begin{abstract}
Aacharaya Sushruta has mentioned 11 types of Shiro-Roga in Uttar Tantra and Kaphaja Shiroroga is one of them. In Kaphaja Shiroroga, there is heaviness in head along with dull pain and numbness in head, feeling of the head being covered with a wet cloth and stiffness. Drowsiness, laziness and anorexia are associated symptoms. Due to predominance of Kapha, sticky mucus secretion in throat, swelling of face and eyes sockets. A sinus headache is caused by mucus build-up as a result of inflammation and pressure within the sinuses during a sinus infection. The pain from sinus headaches is usually more of a dull pain versus a sharp rapid pain. Therefore sinusitis can be considered under the heading of Kaphaja Shiroroga. In the present study, a review is presented on Kaphaja Shirororga and sinusitis to enlighten the correlation and thus providing an alternative treatment option for sinusitis.
\end{abstract}

Keywords: Shiras; Kapha; Paranasal sinuses; Kaphaja Shiroroga; Sinusitis

\author{
Review Article \\ Volume 6 Issue 2 - 2017 \\ Mansi Verma* \\ Department of Shalakya tantra, Ayujyoti Ayurvedic College \\ and Hospital, India \\ *Corresponding author: Mansi Verma, Lecturer, \\ Department of Shalakya Tantra, Ayujyoti Ayurvedic College \\ and Hospital, Sirsa, Haryana, India, Tel: 8742093146; Email: \\ sumansi14@gmail.com
}

Received: February 23, 2017 | Published: March 24, 2017

\section{Introduction}

Various types of Shirorogas are mentioned in Ayurveda classic and Kaphaja Shiroroga is one among them. Similarly in modern science during headache classification, the IHS classified headache from sinus origin which is associated with coexisting symptoms like nasal obstruction, nasal discharge, post nasal drip etc. Sinusitis is an extremely prevalent disorder that has a significant impact on the quality of life of affected individuals. The reason behind this may be the changing lifestyle, urbanization, increasing pollution and increasing resistance to the antibiotics. Being a developing country the incidence of the disease is high among Indian population. The treatment of sinusitis includes antibiotics, decongestants, antihistamines, analgesics and surgical procedures. Although these treatments offer good contributions towards the healing process, but sinusitis is not successfully combated due to its recurrence and well known side effects of the medicines. Fear of surgery, its expense and complications have restricted patients from opting surgery. In view of magnitude of the problem, there is a need to elucidate a therapy within reach of patient and having the potential to drain the sinuses by removing the pathology with sustained effect and reduced recurrence. Therefore the present review on Kaphaja Shiroroga with special reference to sinusitis helps to find out an alternative treatment option like Nasya therapy, Dhoompana, Shamana therapy etc.

\section{Shiras and Kapha}

Shiras (head) is one of the most vital organs ofbody. In Ayurveda, it is listed under Dashavidha Pranayatanas and three Marmas. Shiras is the seat of all Gyanendriyas and controls the functions of Karmendriyas. All the Indriyas, Indriyavahi and Pranavaha Srotas depend on the Shiras for their functions and all the sense organs and the channels carrying the sensory and vital impulses from the Shiras are like the rays from the sun [1]. Ayurveda considers that Vata, Pitta and Kapha are the three pillars of human body. According to Ayurveda seers, Shiras (head) is a place where Kapha is dominant. Kapha, in its normal states of functioning represents a potential source of strength and resistance to disease i.e. Bala and Ojas. Aacharya Charaka described Aatmarupa of Kapha, which are Sneha, Shaitya, Shaukalya, Gaurav, Madhurya, Sthairya, Paichchilya and Matsarya. These properties are responsible for different disease originated from this Dosha [2].

\section{Kaphaja Shiroroga}

\section{Nidana [3]}

i. Aasya Sukha (sedentary life style) .

ii. Swapana Sukha (excessive sleeping or sleeping during daytime).

iii. Guru Bhojana (intake of heavy diet).

iv. Snigdha Bhojana (unctuous diet).

v. Ati Bhojana (excessive food intake).

Due to Sevana of these Nidanas, Kapha is formed in excess which causes Srotorodha and impaired digestion (Mandagni). Due to hypo functioning of Agni, the undigested food residue is formed. This residue is known as Ama and is said to be the root cause of all the disease. As per Amarkosha, "Amyate Peedyate Srotasa Samuho Anena iti Aam" i.e. substance which is detrimental to Srotas is termed as Ama and it produces pain or creates pressure on Srotamukha and accumulates in Srotamukha.

\section{Rupa [4-6]}

Due to indulgence in the above mentioned etiological factors the Kapha gets vitiated and provoked in the head and results in the following sign and symptoms of Kaphaja Shirashoola- 
Kaphaupadigdham Shiras (Feeling of having a coating of phlegm inside the head), Kaphaupadigdam Galam (Post nasal discharge), Guru (Heaviness in the head), Pratishtabdham (Fullness in the head), Himam (coldness in the head), Shuna Akshikoota (swelling around the eyes), Shuna Vadanam (swelling on the face), Aruchi (Anorexia), Mandrujam (mild pain in head), Suptam (Numbness of head), Stimita (stiffness in the head), Shiranispandata (Veins not pulsating), Aalasya (Lassitude), Rukmandaahanya Adhikanishi (mild pain during day time and severe at night), Tandra (Drowsiness), Karnakandu (Itching inside the ears) and Vami (Vomiting).

\section{Samprapti}

Aacharya Charaka explained that as a consequence of indulgence in the Nidanas of Kaphaja Shiroroga, Kapha gets vitiated and lodges in Shirah Pradesh causing Kaphaja Shiroroga(Table 1).

Table 1: Samprapti Ghataka of Kaphaja Shiroroga.

\begin{tabular}{|c|c|}
\hline Dosha & Kapha \\
\hline Dushya & Rakta \\
\hline Adhisthana & Shiras/Mastiska Pradesh \\
\hline Vyakta Sthana & $\begin{array}{r}\text { Akshikoota (Periorbital area), Vadanam (Face), } \\
\text { Nasa (Nose), Galam (Pharynx) }\end{array}$ \\
\hline Agni & Jatharagnimandya \\
\hline Rogamarga & Madhyama \\
\hline
\end{tabular}

\section{Chikitsa}

In Kaphaja Shiroroga, the Kapha subduing measures such as Shirovireka (head purgatives), Teekshna Vamana (emetics) and Gandusha (gargling) should be resorted to [7]. According to Aacharya Charaka, in all types of Shiroroga, Nasya Karma is the prime treatment modality. In the context of treatment of Kaphaja Shiroroga, he has mentioned that after being subjected to sudation (Swedana) and being purified by the administration of Dhoompana, nasal medications (Nasya) and insufflation (Pradhmana) then the patient should be treated well with Lepa, food and drink, curative of Kapha. Purana Sarpi, Teekshna Basti, Agni Karma, Rakta Mokshana should also be used [8].

\section{Sinusitis}

The term, sinusitis, refers to a group of disorders characterized by inflammation of the mucosa of the paranasal sinuses. The newer definition is: Rhinosinusitis is a group of disorders characterized by inflammation of the mucosa of the nose and paranasal sinuses [9]. The paranasal sinuses are air containing spaces in certain bones of skull and they are in direct communication with the nasal cavity through their openings called ostia. They are four on each side- Maxillary sinus, Frontal sinus, Ethmoidal sinus and Sphenoid sinus [10]. The sinus most commonly involved is the maxillary sinus followed in turn by ethmoid, frontal and sphenoid. Very often, more than one sinus is involved (multisinusitis). Sometimes all the sinuses are involved, resulting in pansinusitis [11].

\section{Epidemiology}

Sinusitis is an extremely prevalent disorder that has a significant impact on the quality of life of affected individuals.
According to the National Ambulatory Medical Care Survey (NAMCS), approximately $14 \%$ of adults report having an episode of rhinosinusitis each year, and it is the fifth most common diagnosis for which antibiotics are prescribed, accounting for $0.4 \%$ of ambulatory diagnoses [12]. In India chronic sinusitis affects nearly 134 million people, making it the country with the second largest number of sufferers in the world. 1 in 8 Indians suffer from chronic sinusitis [13].

\section{Pathophysiology}

An inflammatory response is an expected sequel of an infectious process. Inflammation in the nose and sinuses from a variety of causes can result in sinus ostia obstruction and predispose to the development of an infection. Acute rhinosinusitis develops in conjunction with an acute viral upper respiratory tract infection. Antigen-antibody reactions result in the release of inflammatory mediators which cause changes in vascular permeability, destabilization of lysosomal membranes and other reactions that produce inflammation, mucosal swelling and ostia obstruction. A reduction in oxygen tension occurs which can reduce mucociliary transport and transudation of fluid into the sinuses. The inflammation also results in change in the mucous that becomes more viscous and alterations in cilia beat frequency often occurs. These changes in the nasal-sinus environment lead to mucostasis [14].

In chronic infections, process of destruction and attempts at healing proceed simultaneously. Sinus mucosa becomes thick and polypoidal (hypertrophic sinusitis) or undergoes atrophy (atrophic sinusitis). Surface epithelium may show desquamation, regeneration or metaplasia [15].

\section{Diagnosis (Table 2)}

Table 2: Conventional criteria for the diagnosis of sinusitis based on the presence of at least 2 major or 1 major and $\geq 2$ minor symptoms [16].

\begin{tabular}{|c|c|}
\hline Major Symptoms & Minor Symptoms \\
\hline $\begin{array}{c}\text { Purulent anterior nasal discharge } \\
\text { Purulent or discolored posterior } \\
\text { nasal discharge }\end{array}$ & Ear pain, pressure, or fullness \\
\hline Nasal congestion or obstruction & Halitosis \\
\hline Facial congestion or fullness & Dental pain \\
\hline Facial pain or pressure & Cough \\
\hline Hyposmia or anosmia & $\begin{array}{c}\text { Fever (for subacute or chronic } \\
\text { sinusitis) }\end{array}$ \\
\hline Fever (for acute sinusitis only) & Fatigue \\
\hline
\end{tabular}

\section{Treatment}

Medical treatment remains the mainstay of treatment which includes antibiotics, systemic decongestants, local nasal decongestants like- $1 \%$ ephedrine or $0.1 \%$ oxymetazoline or xylometazoline (not for $>5$ days because of the potential for rebound congestion and development of rhinitis medicamentosa) and analgesics. Surgical intervention is done if the infection fails to resolve with medical treatment. Now a day's FESS (Functional endoscopic sinus surgery) is the treatment of choice for various types of sinusitis. 


\section{Discussion}

\section{Shiras and Paranasal sinuses}

Shiras (Head) is considered as Uttamanga, occupying prime place, therefore Shalakya Tantra is also named as Uttmanga Chikitsa. All the Indriyas, Indriyavahi and Pranavaha Srotasa depend on the Shiras for their functions. According to modern science, skull or head consists of the calvaria or brain box which encloses the brain and the facial skeleton lodging all structures of face including the sense organs viz. eye, ear, nose, and tongue. Brain is the body's control center. All the functions of body like digestion, respiration, circulation, sensations, thoughts, communications etc. are based on this framework of head. Therefore paranasal sinuses which are air filled spaces in the bones of skull are one among the structures of Shiras (Head).

\section{Kaphaja Shiroroga and Sinusitis}

Headache is a term commonly used for pain felt anywhere in the head and is described under the heading of Shirorogas in classics. Sinus headache or headache due to sinusitis is caused by mucus build-up as a result of inflammation and pressure within the sinuses during a sinus infection. The pain from sinus headaches is usually more of a dull pain. In Ayurveda also, Mandruka is mentioned in Kaphaja Shiroroga due to accumulation of vitiated Kapha in shirah pradesh.

Nidanas mentioned for Kaphaja Shiroroga like Aasya Sukha, Swapana Sukha, Guru, Snigdha and Ati bhojana points toward the changing life style which is a significant cause in etiology of sinusitis. Internally Khavaigunya in Shiras occurs due to vitiated Kapha as a result of above mentioned Nidana sevana while externally due to Raja (pollen grains, dust particles, feather, animal dander etc.), Dhoom, Sheet Vayu and Pragvata sevana.

Aacharya Sushruta described that the vitiated Doshas travel all around the body and lodge at sites where Khavaigunya exist producing Vyadhi [17]. Khavaigunya in Shiras occurs due to vitiated Kapha. Therefore while Ama circulating in the whole body with the help of Vata, the chief presentation of the disease occurs in the Kapha Sthana i.e. in Shiras as Khavaigunya found at that place. Khavaigunya may be compared to nasociliary destruction or swollen and thickened mucosal lining of the sinuses as a result of inflammatory response. According to modern science, pathology that mainly contributes to the evolution of sinusitis is:

i. Edematous obstruction of sinus ostia resulting in retention of the discharge in the sinus.

ii. Diminished mucociliary transport.

iii. Fall of $\mathrm{pO}_{2}$ within the sinus due to impaired ventilator exchange.

The principle aim of the treatment is also somewhat same. In Kaphaja Shiroroga treatment, main concentration is given to the Dosha Apkarshana from Urdhvajatru Pradesha by administrating Teekshna Nasya, Kavala, Dhoompana, Vamana etc. The modern system of medicine also concentrates to proper drainage and ventilation of sinuses through medical and surgical management. The main treatment which can drain the retained discharge (vitiated Kapha) from the sinuses is Shodhana Nasya. Nose being the doorway to head and Nasya drug extracts the morbid Doshas from the head.

\section{Conclusion}

Paranasal sinuses which are air filled spaces in the bones of skull are one among the structures of Shiras (Head). Most of the description of Kaphaja Shiroroga is similar to sinusitis. Therefore sinus headache or sinusitis can be considered as Kaphaja Shiroroga. Considering the points like side effects of medicines, developing resistance of antibiotics, cost, fear and complications of surgeries, above mentioned Ayurveda treatment modalities of Kaphaja Shiroroga are quite safer and have the potential to drain the sinuses along with immunomodulation.

\section{References}

1. Agnivesh, Charaka Samhita (2008) Vidyotini Hindi commentary. Chaukhamba Bharti Academy, Varanasi, India, pp. 1051.

2. Agnivesh, Charaka Samhita (2008) Vidyotini Hindi commentary. Chaukhamba Bharti Academy, Varanasi, India, pp. 405.

3. Agnivesh, Charaka Samhita (2008) Vidyotini Hindi commentary Chaukhamba Bharti Academy, Varanasi, India, pp. 334.

4. Agnivesh, Charaka Samhita (2009) Vidyotini Hindi commentary. Chaukhamba Bharti Academy, Varanasi, India, pp. 334

5. Sushruta, Sushruta Samhita (2008) Ayurveda Tattva Sandipika Chaukhambha Sanskrit Sansthan, Varanasi, India, pp. 161.

6. Vagbhata, Ashtangahridayam (2008) Vidyotini Hindi Commentary. Chaukhambha Prakashan, Varanasi, India, pp. 726.

7. Sushruta, Sushruta Samhita (2009) Ayurveda Tattva Sandipika Chaukhambha Sanskrit Sansthan, Varanasi, India, pp. 176.

8. Agnivesh, Charaka Samhita (2005) Kashinath Shastri and Gorakhnath Chaturvedi. Chaukhamba Bharti Academy, Varanasi, pp. 750 .

9. http://www.crcnetbase.com/isbn/978-0-340-80893-1

10. https://docs.google.com/file/d/0B-Z6-qAl9s nSDBHTmtJNHJTWG8/view

11. https://docs.google.com/file/d/0B-Z6-qAl9s nSDBHTmtJNHJTWG8/view

12. Bishai WR (2002) Issues in the management of bacterial sinusitis Otolaryngol Head Neck Surg 127(6 Suppl): S3-S9.

13. http://timesofindia.indiatimes.com/india/1-in-8-Indians-hit-bychronic-sinusitis-Study/article show/

14. Michael J Gleeson, Ray C Clarke (2008) Scott-Brown's Otorhinolaryngology Head and Neck Surgery. ( $7^{\text {th }}$ edn), CRC Press, pp. 1440-1441.

15. PL Dhingra, Diseases of ear, nose and throat, 4th edition, pp. 185.

16. Chow, Benninger MS, Brook I, Brozek JL, Goldstein EJ, et al. (2012) IDSA Clinical Practice Guideline for Acute Bacterial Rhinosinusitis in Children and Adults. Clin Infect Dis 54(8): e72-e112.

17. Sushruta, Sushruta Samhita (2009) Ayurveda Tattva Sandipika. Hindi Commentary by Kaviraja Ambikadutta Shastri, Chaukhambha Sanskrit Sansthan, Varanasi, India, pp. 133 